\title{
Dini Kurgu Eserlerin Çevirisine Postyapısalcı Bir Yaklaşım
}

\section{A Poststructuralist Approach to the Translation of Religious Fictions}

\author{
Araştırma/Research
}

\section{Cihan ALAN}

Arş. Gör. Dr., Hacettepe Üniversitesi, Edebiyat Fakültesi, Mütercim ve Tercümanlık Bölümü, cihanalan@hacettepe.edu.tr, ORCID ID: orcid.org/0000-0001-5220-3473

\section{ÖZET}

Bu makalenin amacı, postyapısalcı bir bakış açısıyla kaynak metnin tek başına var olabildiğinden söz edilemeyen bir düzlemde kurgu eserlerde dini öğelerin erek kültürde nasıl yeniden bağlamlaştırıldığını ve bu süreçte çevirilerin birbirlerini nasıl etkilediğini incelemektir. Bu amaçla, çalışmada Lev Nikolayeviç Tolstoy'un Çem lyudi Jivi (Insan ne ile yaşar) adlı öyküsünün Türkçe çevirileri, Lawrence Venuti'nin 'yerlileştirme', 'kalıntı' ve Jacques Derrida'nın transformation regleé (1981) kavramları bağlamında tartışılmaktadır. Derrida'nın gösterenin ve gösterilenin örtüşmediği gösterge yapısında çeviri eylemi düzenlenmiş dönüştürme hali almaktadır. Buna paralel, Venuti'ye göre, çeviride, "kalıntı" adı verilen, ortadan kaldırılması mümkün olmayan bilinçli ya da bilinçdışı kayıplar ortaya çıkmaktadır. Tolstoy'un öyküsünün Türkçe çevirilerinde de iki yönlü bir kalıntı gözlenmiştir: ilki kaynak metnin göstergesel yapısını ve dokusunu oluşturan metiniçi etkisinde kaybına dair kalıntı; ikincisi ise, ortaya çıkan yeni göstergenin bulunduğu kültür içinde söylemsel ve ideolojik koşullara bağlı olarak yeni bir anlamsal sabit oluşturmaya çalışmasından kaynaklı kalıntı. Bazı çevirilerde yerlileştirme nedeniyle yazarın bambaşka bir kimlikle yeniden inşa edildiği, diğer çevirilerin ise zamansal bir döngü içinde bu sabiti yeniden yapısöküme uğratarak belli bir yabancılık etkisi yaratmaya çalıştığı görülmüştür.

Anahtar Sözcükler: postyapısalcılık, indirgenemez farklılık, yeniden bağlamlaştırma, kalıntı, yerlileştirme

\section{ABSTRACT}

The aim of this article is to examine, within a poststructuralist framework where the source text cannot be said to exist alone, how religious elements are recontextualized in the target culture and how translations affect each other in this repruduction process. To this end, Turkish translations of Lev Nikolayevich Tolstoy's short story Çem lyudi Jivi (What Men Live By) are 
discussed on the basis of Venutian concepts of 'domestication' and 'remainder', and Jacques Derrida's concept of transformation regleé. In Derrida's signification proces, where the signifier and the signified do not coincide, translation becomes a regulated transformation. In line with this view, according to Venuti, conscious or unconscious losses called "remainder" appear in the translation process. In the Turkish translations of Tolstoy's short story, the remainders observed are two folds: the first is the one in the intratextual influence that forms the semiotic structure and texture of the source text; and the second is the remainder left in the source text due to translators' search for fixing new signs for the religious elements depending on the discursive and ideological circumstances in the target culture. It has been observed that in some translations, the author is reconstructed with a completely different identity due to domestication, while other translators try to create a foreign effect by deconstructing this stable meaning within a temporal loop.

Keywords: poststructuralism, irreducible difference, recontextualization, remainder, domestication

\section{Giriş}

Kültürel kavramların bir bileşeni olarak düşünülen dini öğelerin çevirisi, başta ideoloji olmak üzere, erek kültür dinamiklerinden arınık bir biçimde incelenemeyecek bir olgudur. Çevirinin anlamları erek kültür içinde yeniden şekillendiren veya üreten bir süreç olarak ele alındığı 1990'lı yıllardan günümüze, kaynak metne sadakat ve ihanet gibi dikotomik yaklaşımlar, yerini çevirmenin manipülasyonu ve çevirinin kaynak ile hedef arasında köprü kurma işlevi tartışmalarına bırakmıştır (Bassnett, 2002, s. 10). Bir toplumun ideolojik aygıtlarından olan din kurumu da çevirmenlerin bu müdahaleci üretim sürecinde kullanışlı ve yönlendirici bir alan oluşturmaktadır.

Dini öğelerin çevirisini salt eşdeğerlik odaklı yaklaşımlarla değerlendirmek çeviri olgusunun günümüz algılanışı içinde sığ çıkarımlarda bulunmanın ötesine geçirmeyecektir. Postmodern anlamda çeviri, sabit ve değişmez anlamların bir dilden ya da kültürden bir diğerine aktarımından ziyade bir dilin veya metnin yapısökümcü bir düzlemde bir diğeri aracılığıyla dönüştürülmesine işaret eder (Arrojo, 2010, s. 249). Geleneksel çeviri kuramları çeviri olgusunu, temelini Fransız yapısalcılık ve Rus biçimcilikten alan, eşdeğerlik kavramı ile açıklamaktadır. Buna göre, anlamların zaman ve uzamdan arınık bir şekilde sabit ve değişmez bir yapıya sahip oldukları için diğer dillere aktarımları olasıdır. Postyapısalcı bir bağlamda ise göstergeler aşkın [ing. transcendental] bir yapıya sahip değildirler ve başka göstergelerle olan ilişkileri sayesinde değişkenlik gösterirler. Bu nedenle, bir dil sistemi içinde oluşan anlamlar diğer dildeki bağlam içerisinde üretilen yepyeni göstergelere dönüşürler. Bu düzlemde dini kavramların çevirisinde, erek kültürün dinamikleri ortaya çıkacak yeni kavramsallaştırmanın ne yönde olacağının belirleyicisidir. Sonuç olarak, ortaya çıkan bu yeni üründe dini kavramlar erek okuyucunun beklentileri doğrultusunda çeviri sürecinde devreye giren birçok aktörün müdahalesiyle farklı kavramsal görünüme bürünür.

Bu çalışmada, kurgu eserlerinde dini öğelerin, yerlileştirme ve yabancılaştırma yöntemleri kullanılarak, ne ölçüde (yeniden) kavramsallaştırılabileceğine, söz konusu kavramların erek kültürde hangi çeviri dinamikleri düzleminde oluştuğuna değinilecektir. 
Bu bağlamda makalenin amacı, eşdeğerlik odaklı bir yaklaşımdan beklenebileceği gibi, kaynak ve erek metin arasındaki uyuşmazlıkları göstermek değil, daha ziyade kaynak metnin tek başına var olabilmesinin mümkün olmadığı postyapısalcı düzlemde dini öğelerin erek kültürde nasıl yeniden bağlamlaştırıldığının ve bu süreçte çevirilerin birbirlerini ne ölçüde etkilediğinin incelenmesidir. Bu amaç doğrultusunda, çalışmada Rus yazar Lev Nikolayeviç Tolstoy'un Çem lyudi Jivi (Insan ne ile yaşar) adlı öyküsünün Türkçe çevirileri Lawrence Venuti'nin 'yerlileştirme', 'kalıntı' ve Jacques Derrida'nın transformation regleé (1981) kavramları bağlamında tartışılacaktır.

\section{Kuramsal Bakış}

\section{1. Postyapısalcılık ve transformation regleé}

Dini öğelerin kültürlere göre değişkenlik gösteren hedef kitle alıcılığı ve bu alıcılığı besleyen ideolojik kurumların üreticiliği erek dilde kaynağın ortadan tamamen kaybolduğu bir göstergeler mücadelesi ortaya çıkarır. Bu nedenle, yeniden üretim sürecinden çıkan çevirileri postyapısalcı düzlemde tartışmak kaçınılmaz hale gelmektedir. Postyapısalcığın çeviri üzerindeki etkisi 1990'lar itibariyle daha belirgin hale gelmiştir. Çeviriye postyapısalcı yaklaşım, özellikle Bassnett ve Lefevere'in (1990) kültürel dönüşüme işaret eden derlemelerinde benimsenen tutum ve eleştirel kuramların çeviri üzerindeki etkisiyle tarihsel paralellikler göstermektedir. Bunun yanı sıra çeviribilimin sömürgecilik-sonrası kuram ve toplumsal cinsiyet çalışmalarıyla kurduğu ortaklıklar, çevirinin odağını çeviri sürecinde gerçekleşen kaymalardan uzaklaştırarak anlamların erek kültürde şekillendirilmesi fikrine yöneltmiştir.

Posyapısalcılığı, çeviriye kültürel dönüşüm sonrası etki eden diğer yaklaşımlarla benzer bir çerçevede, cazip kılan sabit, bilinebilir, anlaşılabilir ve erişilebilir bir özgün metnin varlığını reddediyor olmasıdır. Bu yaklaşım temelini Saussure'cü gösterge modeline karşıtlıktan alır: Saussure'e göre, dilsel gösterge, gösteren ile gösterilenin bir kağıdın iki yüzü gibi birbirinden ayrılmaz şekilde bir arada bulunduğu bir birleşim yapısıdır (Sarup, 1993, s. 33). Bu yapı sayesinde göstergelerin birbirlerinden ayırt edilebilir özleri bulunmaktadır ve anlamlar sadece bu özlerin içindedir (Belsey, 2002, ss. 19-20). Çeviriye eşdeğerlik temelli yaklaşımlarda göstergelerin bu yapısı anlamların belirgin ve ulaşılabilir olmasını sağlar ve bu şekilde aktarılabilirliği -diğer bir deyişle çevrilebilirlik/çevrilemezlik- sorgulanır. Postyapısalcılık ise, çeviri kuramları bağlamında bakıldığında, bir başka dilde yeniden oluşturulması beklenen değişmez anlamlar varsaymak veya dili bu değişmez anlamlardan ayrı tutmak yerine, dilin daha önce hiç konuşulmayan anlamları ürettiğine vurguda bulunarak özgün metni istikrarsızlaştırır ve yapısöküme uğratır (Gentzler, 2001, s. 149).

Derrida'nın (1981) çeviriye yaklaşımının temelinde de göstergeyi birleşim yapısı olarak gören Saussure'cü anlayışının aksine, gösterenin ve gösterilenin farklılığı bulunmaktadır. Ona göre, bu ikili arasında bir örtüşme söz konusu değildir; birbirlerinden sürekli ayrılırlar ve yeni birleşimler meydana getirirler. Aşkın gösterilenlerden söz edilemediği için çeviri Derrida için transformation regleé (bundan böyle 'düzenlenmiş dönüştürme') halini alır. Bu işlemde, arı gösterilenlerin, diğer deyişle özcü anlamların, dillerarası ya da aynı dil içinde aktarımı değil, bir dilin bir başka dile veya 
bir metnin bir başka metne dönüştürülmesi söz konusudur (s. 171). Venuti (2013), aşağıda da değinileceği gibi, Derrida'nın bu yeni çeviri düzleminde kaynak metnin maddeselliğinin yeniden yaratılamadığından, metnin kendi bağlamından koparılarak bambaşka bir bağlamın içine yerleştirildiğinden bahseder. Dolayısıyla, düzenlenerek dönüştürülen bir metin kendi bağlamı içinde kazandığı anlamlardan arınmış, bulunduğu yeni ortamda sürekli bir devinime uğrayarak farklı anlamlandırmaların izlerini taşıyan bir varlıktır.

Derrida'nın düzenlenmiş dönüştürme kavramı postyapısalcılığın çeviride kendini bulduğu en radikal düşüncelerden birini de beraberinde getirir: özgün metnin çeviriden bağımsız var olamaması. Buna göre, özgün eser çeviri sürecinde bir başka akıl tarafından tanımlanır, ortaya çıkan metin yeni okumalar ve başka çevirilerle yeniden anlamlandırılır. Böylece, bu geriye dönük [ing. regressive] anlamlandırma sürecinde ortaya çıkan anlam hedef dilden, kaynak metin de hedef metinden ayrı düşünülemez (Gentzler, 2001, s. 147; Gentzler, 2017, s. 9). Her bir çeviriyi ayrı birer okuma veya anlatı olarak gördüğümüzde, "yazarın ölümü" (Barthes, 1988) de kaçınılmaz hale gelmektedir.

Yazı, bir olgu nesnesi, olmayan amaçlar için anlatıldığı ve gerçeklik üstünde daha fazla doğrudan etkide bulunamaz olduğu bir durumda, başka bir deyişle bir boşluğun göründüğü, simgenin kendi etkinliğinin beklenen herhangi bir işlevinin dışında, sesin kökenini yitirdiği ve Yazar’ın kendi ölümüne girdiği zaman başlar. (Barthes, 2007, s. 55)

Barthes'ın 'yazı' olarak tarif ettiği eylem esasen postyapısalcı bir çeviri sürecini de tarif etmektedir: yazı, söz konusu durumda çeviri, metne bir giz, bir nihai anlam yüklemek, yani sabit anlamları, reddetmek anlamına gelir (Barthes, 1988, s. 171). Artık kaynağın varlığı yitirilmiş, çeviriyle ortaya çıkan yeni metin onun yerini almıştır. Dolayısıyla söz konusu eserle ilgili herhangi bir üstyorum -örneğin ilgili eserin erek kültürde ne gibi etkiler bırakacağı- bu yeni metin üzerinden yapılacaktır. Bu anlamlandırma/çeviri süreci tekil olarak da kalmaz; tıpkı her bir göstergenin bizi başka göstergelere yönlendirdiği gibi, her bir çeviri de önceki çevirilerden anlamsal izler taşır (Gentzler, 2001, s. 147). Bu anlayışla Saussure'ün, anlamları istikrarlı yapılar olarak açıklayan, gösterilenle gösterenin ayrılmazlığı ilkesinin çeviri olgusunu tarif etmede yetersiz kaldığı aşikârdır. Yine, bu çerçevede çeviriyi anlamların "kişiden arınık bir aktarımı” olarak görmenin mümkün olmadığı ortaya çıkmaktadır (Arrojo, 2010). Sonuç olarak, postyapısalcılık çeviriyi salt eşdeğerlik temelli dikotomiler temelinde gerçekleşen bir süreç olarak ele almaz, daha çok sonsuz anlam olasılıkları aracılığıyla ayrımları uzlaştırıcı bir süreç olarak görür.

\subsection{Yerlileştirmenin Bıraktığı Kalıntı}

Venuti'nin yerlileştirme ve yabancılaştırma yöntemleri her ne kadar kuralcı [ỉng. prescriptive ] eşdeğerlik yaklaşımlarına benzer dikotomik çıkarımlar sunuyor gibi görünse de kuramsal çerçevesini Derrida'nın indirgenemez farklılıklar [ing. irreducible difference] yaratan çeviri anlayışına dayandırır ve böylece dilsel göstergelerin dillerarası aktarımını iki kutuplu bir eksende değerlendirmez. Daha ziyade çeviriyi erek kültür içinde yeniden yazım sürecinde sürekli bir gösterge üretimi olarak görür ve bu üretimin o kültürün gereksinimleri içinde şekillendiğinden bahseder (Venuti, 2008; Venuti, 2013). Ona göre, 
kaynak metnin maddeselliği çeviri yoluyla kaçınılmaz bir şekilde ortadan kalkar ve iki yönlü bir kayıp gerçekleşir: ilki kaynak metnin anlamlandırma sürecini ya da biricik dokusunu oluşturan metiniçi etkisinde gerçekleşen kayıptır; bu durum kaynak metni oluşturan bağlamın bileşenlerinden ayrılmasıyla, diğer bir deyişle sökülmesiyle, ortaya çıkar. İkincisi kayıp ise, çeviri yoluyla oluşturulan yeni gösterge zincirinin anlamsal olasılıkları arttırmasından ve çevirmenin bu şekilde hem kaynak metni yansıtacağını düşündüğü bir gösteren sabitleme, hem de alıcı kültürde anlaşılabilirliği ve ilgi çekiciliği sağlama kaygısıyla bu olasılıklar içinden yaratıcılığını kullanarak tercihlerde bulunmasından kaynaklanmaktadır (2013, s. 35).

Eşdeğerlik yaklaşımlarında bir dereceye kadar bertaraf edildiği düşünülen dilsel ve kültürel farklılıklar, çeviri yoluyla bilinçdışı ya da bilinçli bir şekilde gerçekleşebilmektedir. 19. yüzyıl itibariyle Anglo-Amerikan kültüre "doğruluk" [ỉng. accuracy] ve "şeffaflık" [ing. transparency] ilkeleriyle yapılan çevirilerde gerçekleşen farklılıklar çevirmenler tarafından olduğu kadar alıc kitle tarafından da uzun süre fark edilmemiştir (Venuti, 2013, s. 34). Venuti'ye göre, çeviride odaklanılması gereken şey ortadan kaldırılması mümkün olmayan bu bilinçli ya da bilinçdışı kayıpları incelemek ve bir yabancılık etkisi sağlamak için tüm yaratıcı hamlelerin ne gibi farklılıklar oluşturduğunu tespit etmek olmalıdır (s. 34). Venuti, çeviride meydana gelen bu indirgenemez farklılıklara 'kalıntı' [ing. remainder] adını vermektedir. Kalıntı, bir yandan çeviri dilinin standart kullanımında, diğer yandan da kaynak metnin biçimsel ve anlamsal boyutlarında çeşitlenmelere yol açan dilsel biçimler ve metinsel etkilerden oluşur (2013, s. 37). Kalıntı, çeviride daima işlev gören yerlileştirme sürecinin ve kaynak metnin erek kültürde anlaşılabilirliği ve ilgi çekiciliği sağlamaya yönelik asimilasyonunun en belirgin göstergesidir. Ancak, belirtmek gerekir ki, kalıntı kimi zaman erek kültür okuyucusunun aşina olduğu ve çevirmenler ile editörlerin dayattığı baskın standart dilden sapmalarıyla kendini gösteren yabancılaştırma etkilerini de yansıtabilir (s. 37).

Yerlileştirme ile çeviride kasıtlı olarak kalıntı bırakıldığı durumlar bulunmaktadır. Kaynağın ortada bulunmadığı ve erek metnin sabit olmadığı kültürel çeviride (Pym, 2010, s. 144), bu bilinçli çeviri tercihlerine erek kültürdeki süreçler yön verir. Çeviri sürecinde kaynak metindeki göstergelerden kaçınılmaz kayıplar gerçekleştiği için çevirmen bu kaybı erek metin okuyucusunun ihtiyaçlarını da göz önünde bulundurarak, bir dilsel ya da yazınsal etkiyi karşılamak amacıyla, bir çeşit ikame yoluna gider (Venuti, 2013, s. 38). Kurgu eserlerde dini öğelerin erek kültür okuyucusu dikkate alınarak belli değişikliklere uğratılması bu bilinçli eyleme örnek gösterilebilir. Bilinçli ya da bilinçsiz, bu değişiklikler çeviride "benzerliği" yaratmak amacıyla erek kültürün anlam olasılıklarından faydalanılarak gerçekleştirilir. Bu şekilde, yaratılan etki bakımından alıcı kültürün alışageldiği pratiklere ve değerlere benzerlik sağlanır; ancak yine de bu benzerlikler sağlanmaya çalışılırken "farklılıklar"dan yararlanılır (p. 54).

Erek kültürde çeviri eserin okuyucunun beklentilerine veya yazınsal geleneğe uygunluğu Even-Zohar'ın (1990) dizge kavramıyla da yakından ilişkilidir. Türler arası ilişkiler sonucu devingen bir katmanlaşmanın ortaya çıktığından söz eden Even-Zohar, belli bir dizgede dönemsel etmenlere bağlı olarak bazı eserlerin merkez veya çevre konuma geçtiğinden bahseder. Buna göre, bir yazar veya bir tür belli bir özelliğinden 
dolayı dönemin şartları gereği bir kültürde ilgi odağı olabilir ve o kültürde merkez konuma yükselebilir. Even Zohar'a göre, dizgeler homojen ve sabit yapılar olmadıkları için bir dizgedeki belli metinsel örnekler [ing. textual model] başka kültürlerin dizgelerine bazı işlevleri yerine getirmek için aktarılır (1990, s. 76). Bu aktarım sürecinde, Derrida ve Venuti'nin çeviri olgusunda olduğu gibi, hem aktarılan dizgesel üründe hem de bu ürünün "bütünleştiği" alıcı dizgede bir değişime yol açar (Even-Zohar, 2000).

Kurgu eserlerde kullanılan dini öğelerin erek dizge içinde yeniden bağlamlaştırıması sürecinde anlam olasılıkları kimi zaman bilinçli yerlileştirme etkisi nedeniyle sınırlanır. Çevirmenler ve onları yönlendiren yayınevlerinin bundaki rolü erek kültürde geçerli ve alışılageldik bir işlevi yabancı yazarın yalnızca ismini kullanarak sürdürmekten ibarettir. Yayınevleri belli bir kültüre mal olmuş ve o kültürün dizgesinde yer edinmiş eserleri tespit ederek bu eserlerin erek kültürün dizgesinde devingen bir rol oynayabileceğine karar verir. Bu devingenlik erek yazın sisteminin ideolojik, kültürel ve ekonomik koşullarına bağlıdır (Toury, 1995). Yayınevleri söz konusu koşullar içinde kendi politikalarını sürdürmek amaçı diğer yazın sistemlerinden faydalanırlar ve ideolojik çerçevelerinin içinde kalan çevirmenlerle iş birliği içinde statükoyu sürdürmeye çalışırlar. Böylesi bir süreç sonunda ortaya çıkan yeni metin, kendi kültürü içinde ifade bulduğu metiniçi etkiden kurtulmuş, bütünleştiği yeni ortamda (yani erek kültürde), postyapısalcı bir ifadeyle, anlam oynaklığı bilinçli veya bilinçsiz müdahalelerle dizginlenmiş bir üründür. Bu bağlamda, dini kurguların çevirisinde erek metinde ortaya çıkan dini göstergeler çeviri sürecindeki kalıntıların anlaşılması açısından önemli unsurlar olarak görülebilir. Dolayısıyla, kurgu eserlerin çevirisinde dini öğelerin kültürel farklılıklar zemininde karşılanması, erek kültürde bir söylemsel stratejiyi, bu söylemin amaçlarını ve etkilerini de yansıtır. Venuti'ye $(1998$, s. 188) göre, çeviri etiği kapsamında düşünülmesi gereken de bu ikinci bahsedilendir.

\section{Tolstoy'un Insan Ne Ile Yaşar Öyküsü Üzerine}

1828-1919 yılları arasında yaşamış olan Rus yazınının en önde gelen yazarlarından Lev Nikolayeviç Tolstoy, 1880'li yıllardan itibaren din ve felsefe üzerine derinlemesine sorgulamalara yönelmiştir. Bu yıllardaki eserlerinden yola çıkıldığında, Tolstoy'a göre sabır, çalışma, şükretme, merhamet ve sevgi gibi erdemlere sahip insanlar diğer insanlardan üstündür (Kızılırmak, 2020, ss. 9-10). Yazarın 1881 yılında yayınlanmış İnsan Ne Ille Yaşar öyküsünde ele aldığı temalar da bu felsefesini yansıtır niteliktedir. Tolstoy'un yaşamının belli bir noktasından itibaren din ve ahlak konularına yöneldiğini gösteren emareler de bulunmaktadır. Roman Aleksandroviç Disterlo'ya (2018) göre, Tolstoy kardeşine gönderdiği mektuplarda bahsettiği "bıkkınlıktan”, bu güçlenen ruhani-dini inancının yardımıyla kurtulmaya çalışmaktadır. Disterlo'nun belirttiğine göre, yazar 1891 ve öncesinde yazdığı mektuplarda manevi bunalımlarından, yaşamın zalimliğinden ve baştan çıkarıcılığından dem vurmakta ve bunların kendi içine "umutsuzluk ve inançsızlık tohumları" ektiğini dile getirmektedir (s. 115). Bu umutsuzluk ve inançsızlık tehdidi Tolstoy'u eserlerinde insanın manevi-ahlaki yönüne daha çok odaklanma yoluna götürmüştür. 
Tolstoy, Insan Ne ile Yaşar öyküsünü yazarken kardeşine yazdığı mektuplardaki ruh halini yansıtmaktadır (s. 115). Öyküye göre, Tanrı bir meleğini cezalandırarak insanın içinde ne yaşar, insana ne verilmemiştir ve insan ne ile yaşar sorularının cevabını bulmak üzere yeryüzüne gönderir. Michael adıyla insan halinde dünyaya inen meleği fakir bir kunduracı olan Simon soğuktan donmak üzereyken kurtarır. Simon onu evine alır ve karısı onu doyurur. Yıllarca Simon'ın yanında kunduracı olarak çalışır, ta ki bu üç sorunun cevabını bulup tekrar Tanrı'ya kavuşana dek. Yazar, hikaye boyunca adeta bir psikolog rolü üstlenerek Rus yazın geleneğinin sorduğu ahlaki sorunun cevabını ana karakter Simon'un yaşadığı korku, çaresizlik, olup biteni anlamama gibi çelişkili duyguları üzerinden okuyucuya aktarır (s. 114). Bu onun toplumdaki ahlaki çöküşü çarpıcı şekilde sunma gayretiyle ilişkilidir. Tolstoy, hikayenin başında okuyucu için önsöz işlevi gören (s. 113), Yuhanna İncili'nden sekiz alıntıya ${ }^{1}$ yer verir. Bu özdeyişler, hikayenin ana temasını da oluşturan, "Tanrı sevgisini" vurgulamaktadır. Hikayenin ana fikrine göre, insan kendi menfaatlerinden vazgeçerek toplumun refahını düşünmeye yönelmelidir; bu da ancak Tanrı sevgisiyle gerçekleştirilebilir. Tolstoy'un sanatını inceleyen araştırmacı L. D. Gromova'ya göre, "[y]azar, inanç ve din olmadan bir ömür boyu yaşamanın imkansız olduğuna inanmıştır, onun inanç anlayışı ise Hıristiyan sevgisinin ta kendisidir" (akt. Disterlo, 2018, s. 117). Buna ek olarak, Günay Çetao Kızılırmak'ın Viktor Sklovski'den aktardığına göre, Tolstoy sefalet içinde yaşayan insanlara Puşkin ya da Gogol okutmanın bir anlamının olmadığını düşünmüştür. Bunun yerine halkın kendini bulacağı, İsa'nın yaşam tarzını esas alan öyküler yazılması gerektiğini vurgulamıştır (2020, s. 11). Buradaki Hıristiyan vurgusu Tolstoy'un temel aldığı dini öğretileri, öyküdeki metiniçi etkiyi ve kullandığı göstergeleri anlamak açısından önemlidir. Bir sonraki bölümde ele alınacağı üzere, öykünün bazı Türkçe çevirilerinde yerlileştirmenin etkisiyle çeviri kalıntıları bulunur. Bunların en göze çarpanları ise dini öğelerin bağlamından kopma durumlarıdır.

Yukarıdaki açıklamalarda belirtildiği gibi, öykünün anlamsal kurgusunu ve metiniçi etkisini fakir Rus toplumunda ahlak anlayışı ve İsa'nın öğretisi ışığındaki Hıristiyanlık temellendirir. Özellikle 1990'lı yıllardan itibaren, bazı çevirmenler yayınevlerinin politikaları doğrultusunda hedef kitlelerine yönelik temalar içeren eserleri yerlileştirme yöntemiyle çevirme yoluna gitmişlerdir. Tolstoy'un bu öyküsü de bu nitelikteki eserlerin en tipik örneklerinden biridir. Yayınevleri bu tutumlarını gizleme yolunu da seçmemiştir. Örneğin, eserin Murat Çiftkaya'nın çevirdiği versiyonunda yayınevi tarafından bir önsöz yayımlanmış ve şu sözlere yer verilmiştir:

Tolstoy bize çok yakın. Eserlerindeki kültür motifleri, duygu yoğunluğu ve pırıltılı inanç izleri bizi, onun sanki bizimle birlikte yaşadığı şaşırtmacasına sürüklüyor. ... "Insan Ne ile Yaşar?", insan olmanın, insanca yaşamanın gereklerini anlatıyor. Tolstoy hikayeleriyle, çağın insana küs, insanlığa düşman ve evrenin dengeleriyle çelişkili felsefelerine uyarıcı göndermeler yapıyor. Biraz daha yaklaşmak gerekiyor Tolstoy'a, çünkü o bize bakıyor. Şule Yayınları, 2005, s. 7)

Yayınevi tarafından kaleme alınan bu önsözde geçen "Tolstoy'un sanki bizimle yaşadığı" ve onun "bize bakıyor" olduğu ifadeleri, Schleiermacher'in (1813/1992)

\footnotetext{
${ }^{1}$ Rusça ve İngilizce metinlerde yer alan bu alıntılar birçok Türkçe çeviride metinden tamamen çıkarılmıştır (bkz. Tolstoy, 2005; 2006; 2008a; 2008b; 2008d; 2018; 2019; 2021) 
deyişiyle "okuyucunun mümkün olduğunca rahat bırakıldığı ve yazarın okuyucuya yaklaştırıldığı” (ss. 41-42) bir çeviri anlayışını en baştan düşündürmektedir. Nitekim aşağıda örnekleneceği gibi, birçok dini öğe İslami kavramlar kullanılarak erek dilde yeniden oluşturulmuş ve ortaya, yayınevinin varsaydığı üzere, yerli bir öykü anlatıcısı çıkmıştır.

Benzer şekilde, Akçağ Yayınları'ndan çıkan bir başka çevirisinde ise, yayınevi yazarın İslam dünyasına yakınlığını yayımladıkları önsözde şu şekilde dile getirmektedir:

Tolstoy'un eserlerini Türk okuruna sevdiren şey, yazarın eserlerinde, özellikle de hikâyelerinde Şark felsefesinin, özellikle İslam mutasavvıflarının düşünce ve görüşleri ile örtüşen hususların çoğunlukta olmasıdır. Allah sevgisi, insanlara, hayvanlara ve bütün yaratılmışlara olan sevgi ve şefkat duygusu, komşu hakkını gözetme, helal kazanç, aile bağları, zaman ve onun kullanımı, dünya nimetlerine bağlanmamak gibi hususlar bu hikâyelerin temel konusunu oluştur. (Akçağ Yayınları, 2019, s. 5)

Görülebileceği gibi yayınevi, henüz çeviriye geçmeden okuyucuyu yönlendirmek amacıyla, Tolstoy'un Hıristiyan kimliğine herhangi bir göndermede bulunmaksızın salt Şark-İslam kültürü içinde var olan belli ahlaki kavramları yazar üzerinden vurgulama yoluna gitmektedir. Ortaya çıkan bu "yeni Tolstoy" ise ilgili düşün kültürünün yeniden yorumlayıcısıdır.

Tolstoy'un insan Ne ile Yaşar öyküsü bugüne kadar elliden fazla yayınevi tarafından çevrilmiştir. Bir eserin bu kadar çok yayınevi tarafından çevrilmesi bile başlı başına incelenmesi gereken bir konudur. Bu öykünün çevirileri üzerinden yürütülecek bir postyapısalcı tartışma, sadece çevirmenin kaynak metni alıcı kültürün değerlerine göre yeniden şekillendirdiği yorumuyla sınırlı kalamaz. Oluşan her bir metin aynı zamanda diğer çevirilerden de izler taşır ve çeviriler kendi aralarında bir anlamlandırma yarışına girer. Aynı eserin her bir yeniden çevirisi erek kültürde belli kimlikler oluşturmayı ve kurumsal etkiler yaratmaya yönelik bilinçli bir girişimdir (Venuti, 2013, s. 96). Bu durumda öyküde her çevirmenin ve yayınevinin önceki çevirilerden farklı bir algılama yaratma çabası karşılaştırmayla ortaya çıkacaktır. Bu çalışmada, söz konusu karşılaştırmada faydalanılan çeviriler Tablo 1'de gösterilmektedir.

\section{Tablo 1}

Tolstoy'un "Insan ne ile yaşar" adlı öyküsünün bazı Türkçe çevirileri

\begin{tabular}{llll}
\hline Yayınevi & Çevirmen & Kaynak dil & Yayın yılı \\
\hline Şûle Yayınları & Murat Çiftkaya & - & 2005 \\
Alkım Yayınları & E. Murat Cengiz & - & 2006 \\
Bilge Kültür Sanat Yayınları & Ayşe Banu Karadağ & İngilizce & 2007 \\
Oda Yayınları & E. Murat Cengiz & - & 2008 \\
Antik Yayınları & İhsan Özdemir & - & 2008 \\
Nilüfer Yayıncılık & - & - & 2008 \\
Mesev \& Mors Yayınları & - & - & 2008 \\
Türkiye İş Bankası Kültür Yayınları & Koray Karasulu & Rusça & 2012 \\
İthaki Yayınları & Orhan Ertuğrul Tekin & - & 2018
\end{tabular}




\begin{tabular}{llll}
\hline Akçağ Yayınları & - & - & 2019 \\
Doğan Kitap & Günay Çetao Kızılırmak & Rusça & 2020 \\
Can Yayınları & Çağlar Danacı & Rusça & 2020 \\
Ataç Yayınları & Sedat R. Demir & - & 2021 \\
\hline
\end{tabular}

Rusça eserlerin Türkçeye çevirilerinde ara dil kullanımı sık gözlenmektedir. Rusça aslından çeviri yapıldığı durumlarda yayınevleri bunu açıkça belirtirken, ara dilden çeviri yapıldığı durumlarda yayınevleri kaynak dil bilgisini paylaşmama eğilimi göstermektedirler. Örneğin, Şûle Yayınevi tarafından yayımlanan çeviri, İngilizce öğretmenliği bölümü mezunu olan ve İngilizceden çok sayıda çevirisi olan Murat Çiftkaya tarafından yapılmıştır ("Murat Çiftkaya Kimdir?," t.y., para. 2-3). Ancak, yayınevi çevirinin hangi dilden yapıldığına dair bilgi paylaşmamıştır. Aynı şekilde, Antikçağ Yayınevi tarafından yayımlanan İhsan Özdemir çevirisi de İngilizce ara dilinden yapılmış olmasına rağmen bu bilgi eserin künye sayfasında verilmemiştir. Söz konusu çevirmen İngilizce öğretmenliği alanında akademisyendir ve yine İngilizceden başka çevirileri de bulunmaktadır ("ihsan Özdemir," t.y., para. 1). Benzer durum İthaki Yayınları tarafından yayımlanan Orhan Ertuğrul Tekin çevirisi için de geçerlidir. İncelenen çevirilerde ara dilden çeviri yapıldığı bilgisini paylaşan tek yayın evi Bilgi Sanat Kültür'dür. Bundan yola çıkarak, çevirmen ve kaynak dil bilgisini paylaşmayan çevirilerin ara dilden yapıldığı çıkarımında bulunulabilir. Bu nedenle, öykünün Aylmer-Louise Maude tarafından yapılan ve Gutenberg Projesi kapsamında 2002 yılında yayımlanan İngilizce çevirisine de yer yer başvurulacaktır.

\section{4. Çeviri Bulguları ve Tartışma}

Yukarıda da ele alındığı gibi postyapısalcı bir düzlemde kaynaktan söz etmek belli bir eşdeğerlik yaklaşımı benimsemeyi gerektirir. Ancak bu inceleme bölümünde kaynak olmaksızın çeviri dilinde oluşturulan dini göstergeler/dilsel öğeler üzerinden erek kültür içinde şekillenen yeni anlamlandırmaların nasıl okunabileceği tartışılacaktır. Kurgu eserlerin çevirisinde dini öğelerin kullanımının postyapısalcılık bağlamında tartışılmasıyla iki türlü bilgi elde edilebilir: (1) Dini kavramların her bir çeviride farklı bir bağlamlaştırmayla nasıl çeşitli göstergeler oluşturduğu ve bununla bağlantılı olarak; (2) erek kültürde yeniden üretilen yabancı görünümlü kavramsallaştırmaların yeni çeviriler yoluyla yapısöküme uğratılıp uğratılmadığı. Bu nedenle, söz konusu tartışmayı yürütürken özgün metnin, yukarıda bahsedildiği gibi, hangi koşullar içinde üretildiği, çevirileri ortaya çıkaran erek kültür koşullarının neler olduğu, çevirilerin birbirlerini nasıl etkiledikleri bilgisi yönlendirici olacaktır.

\section{1. Sözcük Düzeyinde Dini Öğeler}

Çevirilerde en çok karşılaşılan dini öğelerin başında Rusça "боr" sözcüğünün karşılığı olarak kullanılan Allah veya tanrı gelmektedir. Çevirilerde bu sözcüklerden sadece birinin kullanımı tercih edilmiştir (bkz. Tablo 2). Birbiri yerine kullanılabileceği düşünülen bu kavramlar alıcı kültürde göstergesel olarak farklı alımlamaları barındırmaktadır. Diyanet İşleri Başkanlığı'nın ("Allah ismi”, t.y. para. 1) açıklamasına göre, "Tanrı" kelimesi, Arapça "ilah" kelimesinin karşılığıdır. "ilah" daha çok, Allah'tan 
başka ibadete layık görülen varlıklar için kullanılır... Bu sebeple Müslümanların, ibadet ettikleri tek yaratıcılarını "Allah" diye anmaları daha doğru olur." İslam dinindeki Allah inancının diğer semavi dinlerdekinden farklı olduğu bilgisinden hareketle çeviride bu sözcüğün kullanılması bilinçli bir yerli kalıntıyı eser içine yerleştirmektedir. Nitekim kökeni Türkçe olan² "Tanrı" sözcüğü bu farktan dolayı daha çok seküler bir bağlamda, dinlerdeki ilahlardan bahsederken veya doğrudan İslam-dışı ilah kavramını karşılamak için kullanılmaktadır.

\section{Tablo 2}

“6or" [ing. God] kavramı için tercih edilen Türkçe karşılıklar

\begin{tabular}{|c|c|c|}
\hline Çevirmen & Yayın yılı & Erek metin \\
\hline $\begin{array}{l}\text { Gutenberg } \\
\text { (Çev. Aylmer-Louise Maude) }\end{array}$ & 2002 & $\begin{array}{l}\text { "No one has ill-treated me. God has } \\
\text { punished me." "Of course God rules all. }\end{array}$ \\
\hline $\begin{array}{l}\text { Şûle Yayınları } \\
\text { (Çev. Murat Çiftkaya) }\end{array}$ & 2005 & $\begin{array}{l}\text { "Beni Allah cezalandırdı." "Elbette Allah } \\
\text { herşeye kadirdir." }\end{array}$ \\
\hline $\begin{array}{l}\text { Alkım Yayınları } \\
\text { (Çev. E. Murat Cengiz) }\end{array}$ & 2006 & $\begin{array}{l}\text { "Hayır; Tanrı cezalandırdı beni." "İyiliği de, } \\
\text { kötülüğü de veren O'dur, elbette." }\end{array}$ \\
\hline $\begin{array}{l}\text { Bilge Kültür Sanat Yayınları } \\
\text { (Çev. Ayşe Banu Karadağ) }\end{array}$ & 2007 & $\begin{array}{l}\text { "Tanrı beni cezalandırıyor." "Tabii ki Tanrı } \\
\text { her şeye kadirdir." }\end{array}$ \\
\hline $\begin{array}{l}\text { Oda Yayınları } \\
\text { (Çev. E. Murat Cengiz) }\end{array}$ & 2008 & $\begin{array}{l}\text { "Hayır; Tanrı cezalandırdı beni." "İyiliği de, } \\
\text { kötülüğü de veren O’dur, elbette." }\end{array}$ \\
\hline $\begin{array}{l}\text { Antik Yayınları } \\
\text { (Çev. İhsan Özdemir) }\end{array}$ & 2008 & $\begin{array}{l}\text { "Beni Tanrı cezalandırdı." "Elbette her şey } \\
\text { Tanrı'dandır." }\end{array}$ \\
\hline $\begin{array}{l}\text { Nilüfer Yayıncılık } \\
\text { (Çev. -) }\end{array}$ & 2008 & $\begin{array}{l}\text { "...beni Allah cezalandırdı." "Ona ne şüphe, } \\
\text { Allah'ın karışmadığı iş olur mu hiç,..." }\end{array}$ \\
\hline $\begin{array}{l}\text { Mesev \& Mors Yayınları } \\
\text { (Çev. -) }\end{array}$ & 2008 & $\begin{array}{l}\text { "Hayır, Tanrı cezalandırdı beni." "İyiliği de, } \\
\text { kötülüğü de veren O'dur elbette,..." }\end{array}$ \\
\hline $\begin{array}{l}\text { Türkiye İş Bankası Kültür Yayınları } \\
\text { (Çev. Koray Karasulu) }\end{array}$ & 2012 & $\begin{array}{l}\text { "Beni Tanrı cezalandırdı." "Elbette her şey } \\
\text { Tanrı'dan gelir,..." }\end{array}$ \\
\hline $\begin{array}{l}\text { İthaki Yayınları } \\
\text { (Çev. Orhan Ertuğrul Tekin) }\end{array}$ & 2018 & $\begin{array}{l}\text { "Beni Tanrı cezalandırdı." “Her şey } \\
\text { Tanrı'dan,..." }\end{array}$ \\
\hline $\begin{array}{l}\text { Akçağ Yayınları } \\
\text { (Çev. -) }\end{array}$ & 2019 & $\begin{array}{l}\text { "Beni Allah cezalandırdı." "Tabii ki her şey } \\
\text { Allah'tandır,..." }\end{array}$ \\
\hline $\begin{array}{l}\text { Doğan Kitap } \\
\text { (Çev. Günay Çetao Kızılırmak) }\end{array}$ & 2020 & $\begin{array}{l}\text { "Tanrı cezalandırdı beni." "Orası öyle, her } \\
\text { şey Tanrı'dan..." }\end{array}$ \\
\hline $\begin{array}{l}\text { Can Yayınları } \\
\text { (Çev. Çağlar Danacı) }\end{array}$ & 2020 & $\begin{array}{l}\text { "Beni Tanrı cezalandırdı." "Elbette her şey } \\
\text { Tanrı'dan gelir,..." }\end{array}$ \\
\hline $\begin{array}{l}\text { Ataç Yayınları } \\
\text { (Çev. Sedat R. Demir) }\end{array}$ & 2021 & $\begin{array}{l}\text { "Beni Allah cezalandırdı..." "Elbette } \\
\text { başımıza gelen iyilikler de kötülükler de } \\
\text { Allah'tandır." }\end{array}$ \\
\hline
\end{tabular}

Tanrı kavramını, İsa'nın öğretisinin Ortodoks kültürüne yansımış şeklinde yer bulan "бor" veya Katolik, Protestan, Anglikan, vb. mezheplerde algılanan şekliyle, god kavramına göstergesel olarak eşdeğer olduğu da söylenemez. Türkçede, Allah sözcüğüne kıyasla tanrı sözcüğünün genel-geçer bir şekilde eşdeğer algılanması, kültürlerin ideolojik

2 "Tanrı" sözcüğü eski Türkçede "tengri" sözcüğünün biçimbilimsel ve anlambilimsel olarak değişime uğramış halidir (Nişanyan Sözlük, t.y.). 
ve söylemsel farklılıkları düşünüldüğünde, bir yanılsamadan ibarettir. Bu nedenle, bazı çevirilerde bir yabancılık etkisi yaratmak için kullanılan tanrı sözcüğü kaçınılmaz bir kalıntıyı beraberinde getirmektedir. Diğer yandan, erek kültürde inşa edilmiş olan "Allah" ve "tanrı" kavramlarının farkılığı çevirilerde, diğer deyişle düzenlenmiş dönüştürmede, belli ideolojilerin sürdürülmesi için araçsal hale gelmektedir. Öyle ki, örneğin, Murat Çiftkaya'nın çevirisinde, diğer çevirilerde rastlanmadık ölçüde, "Allah" sözcüğü içeren ifade ve deyim yer almaktadır:

(2) Yapmazsam Allah şahidim olsun. (s. 11)

(3) Ona elbiselerimi veremem. Allah'ım sen bana bir yol göster! (s. 12)

(4) Uşak; "Allahaısmarladık, ustalar" diyerek gitti. (s. 27)

(5) Ruhunu Allah'a teslim etmeden önce, zorlukla eve yetiştirebildiler. (s. 31)

Kavramın bu denli sık ve erek kültür içinde çeşitli edimsel işlevleri yerine getirecek şekilde kullanımı öyküye yerli bir yazarın elinden çıkmış hissi katmaktadır. Bu duruma çevirmen Murat Çiftkaya'nın çevirmen kimliğinin yanı sıra "dini öykü yazarı" kimliği de katkıda bulunmaktadır ${ }^{3}$. Çevirmenin kendine ait otuzun üzerinde, özellikle çocuklar için, dini öykü kitabı bulunmaktadır. Çevirisini yaptığı eserler de ağırlıklı olarak dini içeriklidir. Allah sözcüğünü tercih eden diğer çevirmenler, tanrı sözcüğünü tercih eden çevirmenler gibi, yukarıdaki durumlarda dini bir bağlamlaştırma yoluna gitmemişlerdir. Murat Çiftkaya çevirisinde Allah sözcüğü yerine Kur'an-ı Kerim'de geçen sözcükler ve "esmâ-i hüsnâ" adı verilen Allah'ın 99 isminden örnekler de yer yer kullanmaktadır:

Bir çocuğu bir göğsüne, diğerini de kollarına verdim ve Rabbin yanına döndüm. (2005, s. 34)

Kadın kendi çocukları olmadıkları halde onlara sevgi gösterince ağladım, kadında Hayat Sahibi Allah'ın varlığını hissettim,... (s. 37)

Sözlük anlamı olarak sahip, ıslah eden, efendi ve yetiştiren gibi anlamları olan Rab sözcüğü (Temizer, 2013, s. 41), Kur'an-ı Kerim'de kullanıldığı şekliyle Allah Teâla'nın isimleri arasında sayılmıştır (s. 43). Türkçede de doğrudan Allah'ın isimlerinden biri olarak kullanılmaktadır (Türk Diyanet Vakfı, t.y., para. 1). Allah'ın 99 isminden biri olan hay'ın (Türk Diyanet Vakfı, t.y., para. 1) karşılığı olan hayat sahibi ifadesi de çevirmenin bilinçli tercihiyle metne yerleştirilmiştir.

\section{Tablo 3}

“часо́вня" [ing. chapel] kavramı için tercih edilen Türkçe karşılıklar

\begin{tabular}{lll}
\hline Çevirmen & Yayın yılı & Erek metin \\
\hline $\begin{array}{l}\text { Gutenberg } \\
\text { (Çev. Aylmer-Louise Maude) }\end{array}$ & 2002 & $\begin{array}{l}\text { By this time he had nearly reached the } \\
\text { shrine at the bend of the road. }\end{array}$ \\
\hline $\begin{array}{l}\text { Şûle Yayınları } \\
\text { (Çev. Murat Çiftkaya) }\end{array}$ & 2005 & Yol kıvrımındaki türbeye yaklaşmıştı. (s. 11) \\
\hline
\end{tabular}

\footnotetext{
${ }^{3}$ Bu durum, çevirmenin habitus'u (Bourdieu, 1977) ile de ilişkilendirilebilir. Çalışma kapsamında ele alınmasa da, ilgili çevirmenin yazar habitus'u içinde yerine getirdiği toplumsal pratiklerin çevirmen habitus'una, dolayısıyla çeviride üretim sürecine doğrudan etkisinin olduğu söylenebilir.
} 
Dini Kurgu Eserlerin Çevirisine Postyapısalcı Bir Yaklaşım

\begin{tabular}{|c|c|c|}
\hline $\begin{array}{l}\text { Alkım Yayınları } \\
\text { (Çev. E. Murat Cengiz) }\end{array}$ & 2006 & $\begin{array}{l}\text { Böyle yürüyüp giderken virajdaki türbeye } \\
\text { varmıştı. (s. 9) }\end{array}$ \\
\hline $\begin{array}{l}\text { Bilge Kültür Sanat Yayınları } \\
\text { (Çev. Ayşe Banu Karadağ) }\end{array}$ & 2007 & $\begin{array}{l}\text { O sırada Semyon neredeyse yol kıvrımındaki } \\
\text { türbeye varmıştı. (s. 8) }\end{array}$ \\
\hline $\begin{array}{l}\text { Oda Yayınları } \\
\text { (Çev. E. Murat Cengiz) }\end{array}$ & 2008 & $\begin{array}{l}\text { Böyle yürüyüp giderken virajdaki türbeye } \\
\text { varmıştı. (s. 9) }\end{array}$ \\
\hline $\begin{array}{l}\text { Antik Yayınları } \\
\text { (Çev. İhsan Özdemir) }\end{array}$ & 2008 & $\begin{array}{l}\text { Bu arada neredeyse dönemeçteki kiliseye } \\
\text { varmıştı. (s. 9) }\end{array}$ \\
\hline $\begin{array}{l}\text { Nilüfer Yayıncılık } \\
\text { (Çev. -) }\end{array}$ & 2008 & $\begin{array}{l}\text { Kunduracı, köşe başındaki küçük kiliseye } \\
\text { yaklaşınca, ... (s. 9) }\end{array}$ \\
\hline $\begin{array}{l}\text { Mesev \& Mors Yayınları } \\
\text { (Çev. -) }\end{array}$ & 2008 & $\begin{array}{l}\text { Böyle söylenerek yürürken, virajın yanındaki } \\
\text { türbeye geldi. }\end{array}$ \\
\hline $\begin{array}{l}\text { Türkiye İş Bankası Kültür Yayınları } \\
\text { (Çev. Koray Karasulu) }\end{array}$ & 2012 & $\begin{array}{l}\text { Böyle konuşarak köşedeki küçük kiliseye } \\
\text { yaklaşan ayakkabıcı,... (s. 4) }\end{array}$ \\
\hline $\begin{array}{l}\text { İthaki Yayınları } \\
\text { (Çev. Orhan Ertuğrul Tekin) }\end{array}$ & 2018 & Yol kıvrımındaki türbeye yaklaşmıştı. (s. 12) \\
\hline $\begin{array}{l}\text { Akçağ Yayınları } \\
\text { (Çev. -) }\end{array}$ & 2019 & $\begin{array}{l}\text { Kunduracı böyle söylenerek köşedeki } \\
\text { mabede yaklaştığı sırada... (s. 11) }\end{array}$ \\
\hline $\begin{array}{l}\text { Doğan Kitap } \\
\text { (Çev. Günay Çetao Kızılırmak) }\end{array}$ & 2020 & $\begin{array}{l}\text { Kunduracı, yol ayrımındaki çan kulesine } \\
\text { yaklaşıyor,... (s. 18) }\end{array}$ \\
\hline $\begin{array}{l}\text { Can Yayınları } \\
\text { (Çev. Çağlar Danacı) }\end{array}$ & 2020 & $\begin{array}{l}\text { Ayakkabıcı, kendiyle konuşa konuşa, yol } \\
\text { ayrımındaki şapele yaklaştı... (s. 13) }\end{array}$ \\
\hline $\begin{array}{l}\text { Ataç Yayınları } \\
\text { (Çev. Sedat R. Demir) }\end{array}$ & 2021 & $\begin{array}{l}\text { Böyle kendi kendine söylenerek köşe } \\
\text { başındaki türbeye varmıştı. (s. 7) }\end{array}$ \\
\hline
\end{tabular}

Çevirilerde öne çıkan bir diğer dini öğe ise Rusça "часо́вня" [İng. chapel] sözcüğü için tercih edilen kavramlardır. Ingilizcede chapel sözcüğüyle karşılansa da iki kavram arasında kültürel farklılıklar bulunmaktadır. Ortodoks kültüründe, özellikle Rusya'da, “часо́вня" kavramıyla anlaşılan yapı küçük formda, sunağı olmayan, bağımsız bir kilise olup; Katolik ve Protestan kültürlerde chapel kavramı daha çok kiliseler içinde odacıklar halinde bulunan mabetleri ifade etmektedir. "часо́вня" Ortodoks kültüründe insanların yaşamın herhangi bir anında Tanrı ile buluşmak için sığındığı, bazen de çeşitli mekanların bir bölümünde yer alan bir tür mabettir ("What is a chapel", t.y., para. 4-5). Bu nedenle, Gutenberg Projesi kapsamında yapılan İngilizce çeviride shrine sözcüğü kullanılarak bu kültürel farklılık İngiliz ve Amerikan okurlara hissettirilmeye çalışılmıştır; ancak bunu yaparken Katolik Kilisesi'ne özgü “isa, Meryem veya bir Aziz'in temsilinin yerleştirilebileceği nişli bir yapı" (Collins, t.y., para. 5) anlamı da bu sayede çeviri metinde kalıntı olarak yerini almıştır.

Rusça ve İngilizce arasındaki göstergelerin anlamsal farklılı̆̆ daha çok mimari ve kültürel özelliklerden kaynaklanırken, kimi Türkçe çevirilerde kullanılan tercihler ideolojik ve söylemsel bir farklılaşmayı beraberinde getirmektedir. Postyapısalcı yaklaşıma göre, her bir çeviri önceki çevirilerden izler taşır. Söz konusu kavramı Türkçede yeniden oluştururken çevirmenlerin türbe sözcüğünü kullanması bunun bir göstergesidir. Bu sözcüğü tercih eden çevirilerin ara dilden yapılmış olması büyük bir olasılıktır. Bunu ikinci dilden çeviri yapıldığını belirten Bilgi Sanat Kültür Yayınevi'nin 
çevirisinden anlamak mümkündür. Öyküdeki diğer kültürel kavramlarda bariz yerlileştirmelere gitmeyen çevirmen kaynak metinde shrine sözcügü için türbe kavramını tercih etmiştir. Büyük olasılıkla çevirmen bu İngilizce kavramın içerdiği kutsal bir kişiye veya nesneye adanmışlık anlamından yola çıkarak bu sözcüğü uygun görmüştür. Geri kalan altı çevirmen de ara dildeki bu kalıntıdan kaynaklı bu yeni metiniçi etkiyi ikinci kez çözerek Türkçede yeni bir bağlamlaştırma yoluna gitmiş ve ilgili kavram için Türkçedeki türbe sözcüğünü kullanarak yeni bir gösteren sabitlemeye çalışmıştır. Türbe, İslam coğrafyasında tanınmış şahsiyetlerin mezar anıtlarına verilen addır (Orman, t.y., para. 1). Anadolu kültüründe türbelerde mezar sahibine ve Allah'a dua edilir, dileklerde bulunulur ve aslında kökeni İslamiyet öncesi kültürlere dayanan bir geleneğe uygun olarak, bez veya çaput bağlanır. Bir önceki örnekte Allah sözcüğünü bilinçli bir tercih olarak kullanan çevirmenler, İslami terimleri kullanma eğilimlerini burada da devam ettirmektedir. Söz konusu yerli etki ve söylem yalnızca ilgili terimin kullanımıyla değil, aynı zamanda bu terimin diğer göstergelerle bütünleşmesiyle de sağlanmaktadır. Örneğin, Sedat R. Demir'in çevirisinde terim şu bağlam içinde kullanılmıştır:

Baktığı şeyi görene kadar iyice yaklaştı ve bu varlığın bir insan olduğunu fark etti. Fakat bu insanın ölü mü yoksa sağ mı olduğu belli olmuyordu. Üzerinde hiçbir kıyafet olmayan bir adam, türbenin duvarına yaslanmış, hiç kımıldamadan ve oturur vaziyette duruyordu. (Tolstoy, 2021, s. 8)

Betimlemede resmedilen çıplak bir adamın çaresizlik içinde türbe duvara yaslanması imgesi, türbe kavramının hedeflenen erek kültür okuyucusun zihninde oluşan gösterilenlerle kaynaşarak daha anlaşılır hale gelmesini sağlamaktadır. Türk kültüründe türbelere yüklenen metafizik anlamlar bulunmaktadır. Buna göre, kimi insanlar türbede yatan kişinin ulu ve Allah katında makbul bir kişi olduğuna inanarak Allah'tan dileklerini bu kişi aracılığıyla dilerler (Canel Çınarbaş, 2015, s. 31). Dolayısıyla, çevirmenler betimlemede karakterin içinde bulunduğu duruma uygun olduğunu düşünerek ve diğer dini öğeler için de benimsedikleri yerlileştirme stratejisiyle tutarlı olarak bu kavramı tercih etmiş ve erek kültür içinde söylemsel-ideolojik bir işlevi yerine getirmişlerdir. Yine, Murat Çiftkaya'nın yaptığı çeviride türbe sözcüğü, söz konusu bağlamı güçlendirmek için bir başka dini öğe ile birlikte kullanılmaktadır:

(9) Bulunduğum tarlanın yanında Allah rızası için yapılmış bir türbe gördüm, barınabileceğimi ümit ederek oraya gittim. (Tolstoy, 2005, s. 35)

I saw, near the field I was in, a shrine built for God, and I went to it hoping to find shelter. (Tolstoy, 2002, s. 15)

İslamiyet'te "Allah'ın kulundan, kulun da Allah'tan hoşnut ve memnun olması" (Türk Diyanet Vakfı, t.y., para. 1) anlamına gelen "rıza" kavramının kullanımıyla oluşmuş ve günlük dile yerleşen "Allah rızası için" ifadesi metnin dini söylemini güçlendirmektedir. Murat Çiftkaya'nın çeviri boyunca bu ve benzeri eklemeleri, metni hedeflediği okuyucu kitlesine daha cazip kılmaktadır. Bunun aynı zamanda Türkçe dini öykü geleneğini yabancı yazın ile destekleyip sürdürme amacına hizmet ettiği de söylenebilir. 
Eserin özellikle Rusça aslından yapılan çevirilerde, çevirmenlerin daha çok Hıristiyan kültürüne ait dini öğeleri kullanma eğiliminde olduğu görülmektedir. Buna göre, Koray Karasulu küçük kilise, Günay Çetao Kızılırmak çan kulesi ve Çağlar Danacı şapel sözcüklerini tercih etmişlerdir. Tarihsel sıralamada incelendiğinde, 2010 sonrası yapılan bu çevirilerin, ara dilden yapılan çevirilerin bıraktığı etkinin ardından, kullanılan dini öğelerle belli bir yabancılık hissi yaratmaya çalıştığı ortadadır. Kavramsal olarak, küçük kilise ve şapel kavramları Rus coğrafyasındaki kilise formunu çağrıştırmak amaçlı kullanılmaktadır. Çan kulesi terimi ise, göstergesel olarak Hıristiyan kültüründe bazen kiliselerin bir parçası, bazen de tek başına bulunabilen bir mimari yapıyı zihinde canlandırmak üzere kullanılmıştır. Tüm bu örneklerden görülebileceği gibi, erek kültür içinde tek bir kavram üzerinden tekil bir eşdeğerlik sağlanamamaktadır; erek dilde farklılıklar şeklinde kendini gösteren kalıntı, erek dilin anlam çeşitliliği sağlayan göstergeler zincirinin bir ürünüdür. Bu zincir halkalarından hangilerinin anlamı oluşturacağını belirleyen ise erek kültürde ilgili alanda çeviri geleneğini yönlendiren ideolojik ve söylemsel etmenlerdir.

\subsection{Metinlerarasılık}

Öykünün bazı çevirilerinde göze çarpan bir diğer unsur da metinlerarasılıktır. Venuti'ye (2013) göre, metinlerarası biçimler kaynak metnin sözcüğü sözcügüne yeniden üretimiyle değil, erek kültür içinde farklı dilsel yapılar ve kültürel söylemler aracılığıyla kişisel yoruma dayalı olarak oluşturulur. Bu yapılandırmanın en tipik örneği de, çevirmenin belli bir benzerlik ilişkisi kurarak kaynak metni oluşturan gösterge zinciri yerine erek dilde bir başka gösterge zincirini koyduğu örneksemeye [ing. analogy] dayalı metinlerarasılıktır (s. 101). Öykünün sonunda insan görünümündeki melek Michael, Tanrı'nın kendisine yönelttiği soruların cevaplarına ulaşır ve melek formuna bürünerek başından neler geçtiğini Simon ve ailesine açıklar. Bunu yaparken de eserin en başında yer alan dini özdeyişlere benzer cümleler kurar. Bu kısımda geçen “Кто в любви, тот в боге и бог в нем, потому что бог есть любовь" [ing. He who has love, is in God, and God is in him, for God is love. (Tolstoy, 2002, s. 16)] ifadesi Türkçeye Murat Çiftkaya tarafından metinlerarası unsurlarla aktarılmıştır. Tablo 4'te tüm inceleme kapsamındaki çevirmenlerin çevirilerine yer verilmiştir.

\section{Tablo 4}

\section{Öykünün Türkçe çevirilerinde metinlerarasılık unsuru}

\begin{tabular}{lll}
\hline Çevirmen & Yayın yılı & Erek metin \\
\hline $\begin{array}{l}\text { Gutenberg } \\
\text { (Çev. Aylmer-Louise Maude) }\end{array}$ & 2002 & $\begin{array}{l}\text { He who has love, is in God, and God is in } \\
\text { him, for God is love. (s. 16) }\end{array}$ \\
\hline $\begin{array}{l}\text { Şûle Yayınları } \\
\text { (Çev. Murat Çiftkaya) }\end{array}$ & 2005 & $\begin{array}{l}\text { Kim severse, Allah'a yaklaşır; Allah da ona } \\
\text { yaklaşır. Çünkü O, sevgiyi yaratandır. (s. 38) }\end{array}$ \\
\hline $\begin{array}{l}\text { Alkım Yayınları } \\
\text { (Çev. E. Murat Cengiz) }\end{array}$ & 2006 & $\begin{array}{l}\text { Seven Tanrı'ya, Tanrı, sevene yaklaşır. } \\
\text { Sevgiyi var eden sadece O'dur çünkü. (s. 31) }\end{array}$ \\
\hline $\begin{array}{l}\text { Bilge Kültür Sanat Yayınları } \\
\text { (Çev. Ayşe Banu Karadağ) }\end{array}$ & 2007 & $\begin{array}{l}\text { Kim yüreğinde sevgi taşırsa Tanrı'ya } \\
\text { yaklaşır; Tanrı da o kişinin yüreğindedir, } \\
\text { çünkü sevgiyi yaratan da O'dur. (s. 34) }\end{array}$ \\
\hline
\end{tabular}




\begin{tabular}{|c|c|c|}
\hline $\begin{array}{l}\text { Oda Yayınları } \\
\text { (Çev. E. Murat Cengiz) }\end{array}$ & 2008 & $\begin{array}{l}\text { Seven Tanrı'ya, Tanrı, sevene yaklaşır. } \\
\text { Sevgiyi var eden sadece O'dur çünkü. (s. 31) }\end{array}$ \\
\hline $\begin{array}{l}\text { Antik Yayınları } \\
\text { (Çev. İhsan Özdemir) }\end{array}$ & 2008 & $\begin{array}{l}\text { Kim yüreğinde sevgi taşırsa o sevgi } \\
\text { Tanrı'dandır ve Tanrı o kişinin yüreğindedir, } \\
\text { çünkü varlığın sebebi sevgidir. (s. 44) }\end{array}$ \\
\hline $\begin{array}{l}\text { Nilüfer Yayıncılık } \\
\text { (Çev. -) }\end{array}$ & 2008 & $\begin{array}{l}\text { Sevgi ile dolu olan insan, Allah'a ulaşmış bir } \\
\text { insandır. Allah bu insanın içindedir, çünkü } \\
\text { Allah sevginin ta kendisidir. (s. 35) }\end{array}$ \\
\hline $\begin{array}{l}\text { Mesev \& Mors Yayınları } \\
\text { (Çev. -) }\end{array}$ & 2008 & $\begin{array}{l}\text { Seven Tanrı'ya, Tanrı sevene yaklaşır. } \\
\text { Sevgiyi var eden sadece O'dur çünkü. (s. 34) }\end{array}$ \\
\hline $\begin{array}{l}\text { Türkiye İş Bankası Kültür Yayınları } \\
\text { (Çev. Koray Karasulu) }\end{array}$ & 2012 & $\begin{array}{l}\text { Seven insan Tanrı́nın, Tanrı da onun } \\
\text { içindedir, çünkü Tanrı sevgidir. (s. 27) }\end{array}$ \\
\hline $\begin{array}{l}\text { İthaki Yayınları } \\
\text { (Çev. Orhan Ertuğrul Tekin) }\end{array}$ & 2018 & - \\
\hline $\begin{array}{l}\text { Akçağ Yayınları } \\
\text { (Çev. -) }\end{array}$ & 2019 & $\begin{array}{l}\text { Seven insan Allah'la, Allah da sevenle } \\
\text { beraberdir. Çünkü Allah, seveni sever! (s. } \\
\text { 46) }\end{array}$ \\
\hline $\begin{array}{l}\text { Doğan Kitap } \\
\text { (Çev. Günay Çetao Kızılırmak) }\end{array}$ & 2020 & $\begin{array}{l}\text { Kim sevgi içindeyse, Tanrı da onun içindedir } \\
\text { çünkü Tanrı, sevgidir. (s. 70) }\end{array}$ \\
\hline $\begin{array}{l}\text { Can Yayınları } \\
\text { (Çev. Çağlar Danacı) }\end{array}$ & 2020 & $\begin{array}{l}\text { Sevgiye ulaşan kişi Tanrı'ya ulaşır ve Tanrı } \\
\text { onun içindedir, çünkü Tanrı sevgidir. }\end{array}$ \\
\hline $\begin{array}{l}\text { Ataç Yayınları } \\
\text { (Çev. Sedat R. Demir) }\end{array}$ & 2021 & $\begin{array}{l}\text { Kim yüreğinde sevgi taşıyorsa, işte o sevgi } \\
\text { Allah'tandır. Allah da, yüreğinde sevgi } \\
\text { taşıyan kişinin kalbindedir. Çünkü, tüm } \\
\text { varlığın sebebi, sevgidir! (s. 43) }\end{array}$ \\
\hline
\end{tabular}

Çevirmenlerin sözcük tercihlerinin yukarıda verilen örneklerle tutarlılık gösterdiği görülmektedir. İçerdikleri mesajlar ve sözcük tercihleri birbirleriyle benzerlik gösterse de, Murat Çiftkaya'nın çevirisi sözdizimsel olarak bazı Kur'an-ı Kerim ayetlerinin Türkçe çevirilerini andırmaktadır. Bu bağlamda, ilgili çeviriyi aşağıdaki ayetler ile karşılaştırmak yerinde olacaktır:

(10) Kim severse, Allah’a yaklaşır; Allah da ona yaklaşır. Çünkü O, sevgiyi yaratandır. (Tolstoy, 2005, s. 38)

(11) ...Allah onları sever, onlar da Allah'ı severler... İşte bu, Allah'ın bir lütfudur. Allah, lütfu geniş olandır, hakkıyla bilendir. (Kur'an-ı Kerim, 2011, 5: 54)

(12) De ki: “Eğer Allah'ı seviyorsanız bana uyun ki, Allah da sizi sevsin ve günahlarınızı bağışlasın. Çünkü Allah çok bağışlayandır, çok merhamet edendir." (Kur'an-ı Kerim, 2011, 3: 31)

Sözdizimsel unsurlara bakıldığında, Allah sevgisinin karşılıklı durumunu belirtmek için, çeviride birinci ayette kullanıldığı şekilde "-de" bağlacının aynı görevle kullanımı, "Allah" sözcüğünün etken bir fiil çatısı içinde kullanımı, geniş zaman fiil çekimi ve ikinci ayette örneklendiği gibi, dilek şart kipiyle oluşturulan birinci tümcenin ardından ikinci tümceye çünkü bağlacıyla başlanması; son olarak, Kur'an ayetlerinin birçoğunda da 
görülebilecek olan, Allah'ın meziyetlerini belirtmek için fiillerin -an/-en yapım ekiyle sıfatlaştırılması (örn. yaratan, bağışlayan, merhamet eden, vb.) ve bu sıfatların -dir bildirme ekiyle sonrandırılması metinlerarasılığı sağlamaktadır. Özellikle Allah sözcüğünü tercih eden ve genel olarak bilinçli bir yerlileştirme stratejisi izleyen çevirmenlerin çoğu yukarıda bahsedilen unsurlardan birkaçını kullanmakla birlikte, Murat Çiftkaya'nın çevirisinde yansıttığı kadar metinlerarası etkiyi yaratamamışlardır. Bu fark Çiftkaya'nın dini metinler çevirmeni ve dini öykü yazarı olmasıyla doğrudan ilintilidir. Kısaca, Tolstoy'un Hıristiyan geleneği içinde kullandığı dini öğelerin erek kültür içinde dini öykü yazım geleneğini sürdürmek amaçlı dönüştürüldüğü görülmektedir. Bu nedenle, yukarıda verilen yerlileştirme örnekleriyle birlikte, çeviri diline ait söylem aracılığıyla Tolstoy’a yerli bir kimlik inşa edilmektedir.

\section{Sonuç}

Bu çalışmada, kurgu eserlerin çevirisinde dini öğelerin, "yazarın ölümü" ile başlayan ve alıcı kültürün anlam olasılıklarının manipülasyonu aracılığıyla yeniden kimlikleştirilmesi sürecinde bir "dönüşüme" uğradığı gösterilmeye çalışılmıştır. Bir dilin kendi kültürü içinde oluşmuş kavramlarının erek dile aktarımında alıcı kültürün anlam olasılıklarından bahsetmek eşdeğerlik arayışını bırakarak postyapısalcı bir yaklaşım benimsemeyi de beraberinde getirmektedir. Dini kavramların algılanması kültür içinde şekillenir: bu kavramlar kurgu eserlerde yazarın zihninde oluşturduğu imgelerle bir göstergeler zinciri içinde üretilir; bir eserin metiniçi etkisini oluşturan da yazarın zihnindeki bu göstergelerdir. Bu noktada, çeviride "benzerlik" (İng. similarity) kavramı oldukça tartışmalı bir hal almaktadır. Venuti'nin (2013) de açıkladığı gibi, kaynak ve erek metin arasında gözetilmeye çalışılan benzerlik, diller arasındaki yapısal, ideolojik ve kültürel farklar üzerinden kurulur. Diğer taraftan, çevirinin hedeflendiği ortama uyumu, yine kaynak ve erek metinde anlam bulan kavramların ve dahası iki sistemin metiniçi ve metinlerarası ilişkiler ağının farklılığı üzerinden sağlanır (s. 54). Dini öğelerin erek kültürde çeşitlilik gösteren kavramlar aracılığıyla aktarımının temelinde yatan bu farklılıklardır. Rusçadaki "бог" kavramı için Allah veya tanrı sözcüklerinin; "часо́вня" kavramı için türbe, mabet, kilise, çan kulesi, şapel sözcüklerinin veya inceleme kısmında değinilmeyen "не́бо" kavramı için gök, gökyüzü, hava, semâ, semâvât; "хвала́" kavramı için de ilahi, kutsama, övgü, şükür, hamd, hamdüsena gibi sözcüklerin tercih edilmesinin temelinde, bu sözcüklerin her birinin kaynak metindekine kıyasla bulunduğu kültürde farklı değerler ve ideolojiler içinde kavramsallaştırılması yatmaktadır. Bu sözcüklere erek kültür içinde anlamsal değerini katan, diğer bir deyişle, çevirideki dini öğelerin bulunduğu kültürle bütünleşmesini sağlayan kaynak kültür koşullarından farklı metiniçi ve metinlerarası bağlantılarla kullanılmalarıdır. Bu nedenle çeviride dini öğelerin aktarımı bu kaçınılmaz ve indirgenemez farklılıklar aracılığıyla gerçekleşir.

Dini öğelerin yeniden bağlamlaştırılmasında göstergelerin mücadelesi erek kültür içinde belli farklılıklar yaratan yeniden çeviriler ortaya çıkarmaktadır. İncelemede ele alınan çevirilere zamansal olarak bakıldığında, farklı türde okuyucu kitleleri hedeflenerek, dini öğelerin aktarımında önceki çevirilerden döngüsel bir farklılaşmaya gidildiği görülmektedir. Bu durum Derrida'nın düzenlenmiş dönüştürme olarak tanımladığı çeviri sürecinin bir parçasıdır. Her yeni çeviride farklı bir algılama yaratmak 
üzere dini kavramların da önceki çevirilerden farklı ideolojiler ve değerler çerçevesinde dönüştürüldüğü, çeşitli metiniçi ve metinlerarası öğeler aracılığıyla okuyucu kitlesinin daraltıldığı görülmektedir. Çevirilerin Rusça aslından ya da İngilizce ara dilden yapılması yeniden çevirilerin bağlamlaştırılmasında önemli bir etken olarak görülmektedir. Birçok yayınevi ara dilden çeviri yapıldığını gizlemiş, hatta bazıları çevirmenin adına dahi yer vermemiştir. Bu durumun yerlileştirme stratejisiyle paralel işlediği yorumunu yaparsak aşırıya kaçmış olmayız. Buna karşın, çevirmen adının ve çevirinin Rusça aslından yapıldığı bilgisini paylaşan Türkiye İş Bankası Kültür Yayınları, Can Yayınları, Doğan Kitap çevirilerinin kendilerinden önce yayımlanan çevirilerdeki dini öğeler üzerinden yaratılan yerli etkiyi yeniden bağlamlaştırma yoluyla kırılmaya uğrattığı görülmüştür. Eserin bu kadar fazla çevirisinin olmasında, Rusçadan çevirilerin Türk yazın dizgesi içinde belli bir kanon oluşturması, Tolstoy ve Dostoyevski gibi yazarların eserlerinde telif sorunu bulunmaması ve bu durumdan faydalanmak isteyen yayınevlerinin ekonomik getiriyi önceleyerek çeviri faaliyetlerine devam etmesi etkendir -öyle ki, Alkım Yayınları ve Oda Yayınları'nda görüldüğü gibi, bir çevirmen tarafından yapılan çeviri birden fazla yayınevi tarafından yayımlanabilmektedir. Dolayısıyla, dini kurguların yeniden bağlamlaştırılması sürecinin belli bir zaman dilimi ardından tek yönlü hale geldiğini söylemek mümkün değildir. Ekonomik nedenler ve buna ek olarak alıcı toplumda din kurumuna ait söylemlerin ideolojik düzlemde yayınevleri tarafından yeniden üretilmesi niyeti geçerli oldukça benzer yerlileştirme örneklerinin kaçınılmaz olduğu açıktır.

Bu çalışmada, Venuti'nin betimlediği Anglo-Amerikan çeviri geleneğinde görülen okunabilirlik ve anlaşılabilirlik odaklı yerlileştirme yaklaşımımın bir farklı boyutu görülmektedir. Dini kurgu eserlerinin çevirilerinde dini öğelerin bir şekilde yabancılaştırılması anlaşılabilirliği ve okunabilirliği sekteye uğratmamaktadır; çünkü ortalama Türk okuyucusu, Batı medeniyeti ve Hıristiyan geleneğine ait birçok kavrama kendi kültürel kavramsallaştırmaları çerçevesinde aşina durumdadır. Bu anlamda, dini öğelerde önceki çevirilere kıyasla yabancılaştırmaya gidildiği şeklinde bir algılama standart dilden sapma olarak yorumlanamaz. Ancak, çevirmenlerin bilinçli bir şekilde erek kültürün dini söylemlerinden ve ideolojilerinden faydalanarak oluşturdukları yeni bağlamlar dini öykü türünü yazın geleneği içinde sürdürme ve bu şekilde belli okuyucu kitlelerini hedefleme amacı taşımaktadır. Bu anlamda, ortaya çıkan yeni metnin, postyapısalcı bir gözle bakıldığında, özgün bağlamından ve yazarından tamamen kurtulduğunu; yazarın ise artık tamamen çeviri üzerinden yorumlanabileceğini, bu nedenle de yazarın bambaşka bir kimliğe büründüğünü (veya ölümüyle anlam bulduğunu) ve bu yeni kimlikli yazarın yeni okumalarda ve çevirilerde izler bırakacağını söyleyebiliriz.

\section{Kaynakça}

Akçağ Yayınları. (2019). Lev Nikolayeviç Tolstoy (d.1828-ö.1910). L. N. Tolstoy, Insan ne ile yaşar? içinde (ss. 4-6). Akçağ Yayınları. 
"Allah" ismi yerine "Tanrı" kelimesini kullanmak caiz midir?. (t.y.). Din İşleri Yüksel Kurulu Başkanlığı. Erişim: 12 Ekim 2021, https://kurul.diyanet.gov.tr/Cevap-Ara/4/-allah--ismiyerine--tanri--kelimesini-kullanmak-caiz-midir-

Arrojo, R. (2010). Philosophy and translation. Y. Gambier \& L. van Doorslaer (Eds.), Handbook of translation studies (Vol. 1) içinde (pp. 247- 251). John Benjamins Publishing Company.

Barthes, R. (1988). The death of the author. D. Lodge (Ed.), Modern crititicism and theory: $A$ reader içinde (ss. 166-172). Longman.

Barthes, R. (2007), Yazarın ölümü. (Çev. Eren Rızvanoğlu), Heves Şiir Eleştiri Dergisi, 14, 55-60.

Bassnett, S. (2002). Translation studies. Routledge.

Bassnett, S., \& Lefevere, A. (1990). Translation, history and culture. Printer Publishers.

Belsey, C. (2002). Postyapısalcılık. (N. Örge, Çev.). Dost.

Bourdieu, P. (1977). Outline of a theory of practice. Cambridge University Press.

Canel Çınabaş, D. (2015). İslami ve İslam öncesi inançlar ve psikoloji: Türkiye'de yerel sağaltım yöntemleri bağlamında türbe ve hoca ziyaretleri. AYNA Klinik Psikoloji Dergisi, 2(1), 27-39. https://doi.org/10.31682/ayna.470651

Collins Dictionary. (t.y.). Shrine. Collindictionary.com. Erişim: 20 Ekim 2021, https://www.collinsdictionary.com/dictionary/english/shrine

Derrida, J. (1981). Positions. (A. Bass, Çev.). University of Chicago Press. (Özgün eser basım yılı 1972).

Derrida, J. (1997). Of grammatology. Johns Hopkins University Press.

Disterlo, R. A. (2018). “Insan ne ile yaşar?” için sonsöz. Tolstoy, L. N. Insan ne ile yaşar?. (O. E. Tekin, Çev.) içinde (ss. 112-118). İthaki.

Even-Zohar, I. (1990). Translation and transfer. Poetics Today, 11(1), 73-78.

Even-Zohar, I. (2000). The position of translated literature within the literary polysystem. L. Venuti (Ed.), Translation studies reader içinde (ss. 192-197). Routledge.

Gentzler, E. (2001). Contemporary translation theories. Multilingual Matters.

Gentzler, E. (2017). Translation and rewriting in the age of post-translation studies. Routledge.

ihsan Özdemir. (t.y.). Academia. Erişim: 15 Ekim 2021, https://ibu.academia.edu/\%C4\%BOhsan\%C3\%96zdemir

Kızılırmak, G. Ç. (2020). Önsöz. Tolstoy, L. N. Insan neyle yaşar. (G. Ç. Kızılırmak, Çev.) içinde (ss. 9-12). Doğan Kitap.

Kur'an-ı Kerim. (H. Altuntaş \& M. Şahin, Ed.). (2011). Diyanet İşleri Başkanlığı.

Murat Çiftkaya kimdir?. (t.y.). d\&r. Erişim: 16 Ekim 2021, https://www.dr.com.tr/yazar/muratciftkaya/s=30829

Nişanyan Sözlük. (t.y.). Tanrı. nisanyansozluk.com. Erişim: 20 Ekim 2021, https://www.nisanyansozluk.com/?k=tengri

Orman, i. (t.y.). Türbe. Türkiye diyanet vakfı İslam ansiklopedisi. Erişim: 21 Ekim 2021, https://islamansiklopedisi.org.tr/turbe 
Pym, A. (2010). Exploring translation theories. Routledge.

Sarup, M. (1993). An introductory guide to post-structuralism and postmodernism. Harvester Wheatsheaf.

Schleiermacher, F. (1813/1992). On the different methods of translating. J. Biguenet \& R. Schulte (Ed.). Theories of translation: An anthology of essays from Dryden to Derrida içinde (ss. 36-54). University of Chicago Press.

Şule Yayınları. (2008). Sunuş. L. N. Tolstoy, Insan ne ile yaşar?. (M. Çiftkaya, Çev.) içinde (s. 7). Şule.

Tolstoy, L. N. (2002). What men live by (L. Maude \& A. Maude, Çev.). Gutenberg Project.

Tolstoy, L. N. (2005). Insan ne ile yaşar? (M. Çiftkaya, Çev.). Şule Yayınları.

Tolstoy, L. N. (2006). Insan ne ile yaşar? (E. M. Cengiz, Çev.). Alkım Yayınları.

Tolstoy, L. N. (2007). Insan ne ile yaşar? (A. B. Karadağ, Çev.) Bilge Kültür Sanat Yayınları.

Tolstoy, L. N. (2008a). Insan ne ile yaşar? (E. M. Cengiz, Çev.). Oda Yayınları.

Tolstoy, L. N. (2008b). Insan ne ile yaşar? (i. Özdemir, Çev.). Antik Yayınları.

Tolstoy, L. N. (2008c). Insan ne ile yaşar? (Anonim, Çev.). Nilüfer Yayınclık.

Tolstoy, L. N. (2008d). Insan ne ile yaşar? (Anonim, Çev.). Mesev \& Mors Yayınları.

Tolstoy, L. N. (2012). Insan neyle yaşar? (K. Karasulu, Çev.). Türkiye İş Bankası Kültür Yayınları.

Tolstoy, L. N. (2018). Insan ne ile yaşar? (O. E. Tekin, Çev.). İthaki Yayınları.

Tolstoy, L. N. (2019). Insan ne ile yaşar? (Anonim, Çev.). Akçağ Yayınları.

Tolstoy, L. N. (2020). Insan neyle yaşar? (G. Ç. Kızılırmak, Çev.). Doğan Kitap.

Tolstoy, L. N. (2020). Insan neyle yaşar? (Ç. Danacı, Çev.). Can Yayınevi.

Tolstoy, L. N. (2021). Insan ne ile yaşar? (R. S. Demir, Çev.). Ataç Yayınları.

Toury, G. (1995). Descriptive translation studies and beyond. John Benjamins Publishing.

Türk Diyanet Vakfı. (t.y.). Hay. Islam ansiklopedisi. Erişim: 20 Ekim 2021, https://islamansiklopedisi.org.tr/hay

Türk Diyanet Vakfı. (t.y.). Rab. İslam ansiklopedisi. Erişim: 20 Ekim 2021, https://islamansiklopedisi.org.tr/rab

Venuti, L. (1998). The scandals of translation. Routledge.

Venuti, L. (2013). Translation changes everything: Theory and practice. Routledge.

What is a chapel and how is it different from a temple?. (t.y.). Uznavay.pro. Erişim: 20 Ekim 2021, http://uznavay.pro/chto-takoe-chasovnya-i-chem-ona-otlichaetsya-ot-hrama/ 